\title{
Bioremediation of engine-oil contaminated soil using local residual organic matter
}

\author{
Kawina Robichaud ${ }^{1}$, Miriam Lebeau ${ }^{2}$, Sylvain Martineau ${ }^{2}$, Marc Amyot ${ }^{\text {Corresp., } 1}$, Nicolas Gruyer \\ 1 Département de sciences biologiques, Université de Montréal \\ 2 Akifer, Boucherville, Canada \\ Corresponding Author: Marc Amyot \\ Email address: m.amyot@umontreal.ca
}

Soil remediation industries continue to seek technologies to speed-up treatment and reduce operating costs. Some processes are energy intensive and, in some cases, transport can be the main source of carbon emissions. Residual fertilizing matter (RFM), such as organic residues, have the potential to be beneficial bioremediation agents. Following a circular economy framework, we investigated the feasibility of sourcing RFMs locally to reduce transport and assess possible bioremediation efficiency gains. RFMs were recruited within $100 \mathrm{~km}$ of the treatment site: ramial chipped wood (RCW), horse manure (MANR) and brewer spent grain (BSG). They were added to the land treatment unit's baseline fertilizer treatment (FERT, ' $F$ ') to measure if they improved the remediation efficiency of an engine oil-contaminated soil $\left(7500 \pm 100 \mathrm{mg} \mathrm{kg}^{-1}\right)$. Results indicate that MANR-F was the only amendment more effective than FERT for petroleum hydrocarbons $(\mathrm{PHC})$ reduction, while emitting the least $\mathrm{CO}_{2}$ overall. $\mathrm{RCW}-\mathrm{F}$ was equivalent to FERT but retained more moisture. Although BSG contributed the most nitrogen to the soil, BSG-F retained excessive moisture, emitted more VOCs, contained less soil $\mathrm{O}_{2}$, and was less effective than the baseline treatment. Significantly more of the $\mathrm{C}_{16}-\mathrm{C}_{22}$ fraction was removed $\left(63 \pm 22 \%\right.$ ) than all other fractions $\left(\mathrm{C}_{22}-\mathrm{C}_{28}, \mathrm{C}_{28}-\mathrm{C}_{34}, \mathrm{C}_{34}-\mathrm{C}_{40}\right)$, which were equally removed. Microbial community-level physiological profiling (CLPP) was conducted with Biolog Ecoplates ${ }^{\mathrm{TM}}$, and catabolic diversity differed between treatments (utilization rates of 31 carbon sources). MANR-F has the potential to increase PHC-remediation speed and efficiency compared to inorganic fertilizer alone. Other RFM promote moisture retention and diverse microbial catabolic activity. A variety of RFM are present across the globe and some can offer low-cost amendments to boost remediation efficiency, while reducing treatment time compared to traditional fertilizer-only methods. 
1 Bioremediation of engine-oil contaminated soil using local residual 2 organic matter

3

4

5

6

7

Kawina Robichaud $^{1}$, Miriam Lebeau ${ }^{2}$, Sylvain Martineau ${ }^{2}$, Marc Amyot ${ }^{1^{*}}$

${ }^{1}$ Center for Northern Studies, Département de sciences biologiques, Université de Montréal, Pavillon Marie-Victorin, 90 Vincent d'Indy, Montréal QC, H2V2S9

${ }^{2}$ Groupe Akifer inc. Quebec City, QC G1N 4K8

* Correspondence:

Marc Amyot

m.amyot@umontreal.ca

Keywords: Petroleum, bioremediation, residual organic matter, circular economy, valorisation.

\section{Abstract}

Soil remediation industries continue to seek technologies to speed-up treatment and reduce operating costs. Some processes are energy intensive and, in some cases, transport can be the main source of carbon emissions. Residual fertilizing matter (RFM), such as organic residues, have the potential to be beneficial bioremediation agents. Following a circular economy framework, we investigated the feasibility of sourcing RFMs locally to reduce transport and assess possible bioremediation efficiency gains. RFMs were recruited within $100 \mathrm{~km}$ of the treatment site: ramial chipped wood (RCW), horse manure (MANR) and brewer spent grain (BSG). They were added to the land treatment unit's baseline fertilizer treatment (FERT, 'F') to measure if they improved the remediation efficiency of an engine oil-contaminated soil $\left(7500 \pm 100 \mathrm{mg} \mathrm{kg}^{-1}\right)$. Results indicate that MANR-F was the only amendment more effective than FERT for petroleum hydrocarbons (PHC) reduction, while emitting the least $\mathrm{CO}_{2}$ overall. RCW-F was equivalent to FERT but retained more moisture. Although BSG contributed the most nitrogen to the soil, BSG-F retained excessive moisture, emitted more VOCs, contained less soil $\mathrm{O}_{2}$, and was less effective than the baseline treatment. Significantly more of the $\mathrm{C}_{16}-\mathrm{C}_{22}$ fraction was removed $(63 \pm 22 \%)$ than all other fractions $\left(\mathrm{C}_{22}-\mathrm{C}_{28}, \mathrm{C}_{28}-\mathrm{C}_{34}, \mathrm{C}_{34}-\mathrm{C}_{40}\right)$, which were equally removed. Microbial communitylevel physiological profiling (CLPP) was conducted with Biolog Ecoplates ${ }^{\mathrm{TM}}$, and catabolic diversity differed between treatments (utilization rates of 31 carbon sources). MANR-F has the 
potential to increase PHC-remediation speed and efficiency compared to inorganic fertilizer alone. Other RFM promote moisture retention and diverse microbial catabolic activity. A variety of RFM are present across the globe and some can offer low-cost amendments to boost remediation efficiency, while reducing treatment time compared to traditional fertilizer-only methods.

\section{Introduction}

Soil treatment centers are constantly seeking new soil remediation technologies to speed up treatment and reduce their production costs. Conversely, organic waste diversion from landfills and processing strategies for sustainable waste management practices are actively being put in place across Europe and North America (CEC, 2017; European Commission, 2010). Organic waste makes up a significant portion of the waste stream going to landfills where its anaerobic decomposition produces polluting gases, like methane, which not only affect human health and air quality, but also contribute to climate change (Lou and Nair, 2009). In Canada, all levels of government aim to reduce greenhouse gas emissions, namely through the reduction of putrescible landfill waste (Environment Canada, 2014). For example, the Quebec Ministry of Environment and Fight Against Climate Change (MELCC) encourages the valorization of residual fertilizing materials (RFM) to divert them from landfills where they become putrescible organic residues. These include, but are not limited to, residential food scraps, agricultural and industrial wastes and wood residues. This diversion, which reached 1.6 million tons in 2012, can be used to revegetate degraded sites and serve as fertilizer in agriculture, thereby helping to reduce greenhouse gas emissions (Larose et al., 2014). Several studies demonstrate the potential of RFM as efficient bioremediation agents when compared to controls (Abioye, 2011; Cole, 1998; Guidi et al., 2012; Hupe et al., 1996; Margesin and Schinner, 1997; Onwosi et al., 2017; Zubillaga et al., 2012). However, the MELCC (2014) reports that only 8\% of salvaged RFM were used on degraded sites and usage on soils contaminated with petroleum hydrocarbons (PHC) was not mentioned. We reported the current practices in the province of Quebec, where our project takes place, but the main principles of organic waste reduction apply across Canada, the US, Mexico and Europe (CEC, 2017; European Commission, 2010).

Further, these main principles are embedded into a circular economy framework. Circular economy is an emerging concept which considers how we can consume goods and services without depending on the extraction of raw natural resources, thereby closing loops that prevent the disposal of materials in landfills (Sauvé et al., 2016). In contrast to the usual 'linear economy' model, the impacts of resource consumption are taken into account. Governments around the world are adopting the concept of circular economy (e.g. China and Europe; see Sauvé et al., 2015). This concept applies to soil remediation practices because some remediation approaches are energyintensive or require large areas of land (landfarming, soil vapor extraction, thermal desorption, etc.) and many depend on the introduction of inorganic fertilizers which rely on energy-intensive synthesis and mining of non-renewable resources, such as phosphorus (Daneshgar et al., 2018; Khan et al., 2004; Rafiqul et al., 2005).

A popular soil remediation approach to large-scale PHC-contamination is the use of low-tech and relatively low-cost biopiles (Ivshina et al., 2015). This remediation method is normally based on the stimulation of endemic microbes for contaminant degradation (Khan et al., 2004). It is optimized through different manipulations such as the addition of nutrients, the modification of soil structure and exerting some control over moisture content and air supply (Juwarkar et al., 2010). In Quebec, regulations require that biopiles must be covered and equipped with a pulled- 
air system and an air treatment system for volatile organic carbon contaminants, like BTEX (benzene, toluene, ethylbenzene and xylenes), methane, hexane and other light PHC molecules having less than 12 carbon atoms $\left(\mathrm{C}_{12}\right)$, prior to release in the atmosphere.

Appropriate nutrient input and timing of application are key for effective bioremediation of PHCcontaminated soils (Nwankwegu et al., 2016). The main sources for nutrients are inorganic fertilizer and organic matter amendments to the contaminated soil. Nitrogen is the most common limiting nutrient, but depending on its form, it may or may not be available for the microorganisms in the soil that biodegrade contaminants (Schulten and Schnitzer, 1997). However, accurately monitoring different forms of $\mathrm{N}$ is sometimes difficult because the microbe-moderated nitrogen cycle in the soil is rapid and complex. Microbes are at the heart of bioremediation techniques like biopiles and it is advantageous to understand how soil amendments may influence them. Community-level physiological profiling (CLPP) is an approach commonly used in ecology for assessing microbial community profiles in soils (Jones et al., 2018). Biolog Ecoplates ${ }^{\mathrm{TM}}$ give a sensitive fingerprinting tool for communities' catabolic diversity. The microplates contain 31 different carbon sources, along with a redox dye which turns purple when the substrate is consumed (Biolog, 2018). Based on a specific soil's heterotrophic bacterial community, different carbon sources are consumed at varying rates, offering a unique look at the functional carbon use in a given soil, which can lead to the statistical differentiation of soils based on Ecoplates ${ }^{\mathrm{TM}}$ data alone (Jones et al., 2018). The method's limits include the issue of poor laboratory cultivability of certain bacterial strains and the challenges associated with the huge amount of data generated. Nonetheless, the data obtained is information-rich and reproducible (Bradley et al., 2006).

For this study, we aimed to find three close-proximity RFM which could be further valorized as biological agents to stimulate the biodegradation of PHCs. 1) Wood residues have been used as bulking agents in bioremediation projects (Battelle and NFESC, 1996; Kauppi et al., 2011). We opted for ramial chipped wood (RCW), a material that has been proven to increase soil fertility (Lemieux, 1986). Its chemical composition has rich ratio of polysaccharides to proteins $(\mathrm{C}: \mathrm{N})$ varying between 50:1 and 175:1 (varying across species and seasons) compared to woodchips from stem wood which have a C:N ratio of 400:1 to 600:1 under the same conditions (Lemieux, 1986). RCW is rarely cited in bioremediation, but Hattab et al. (2015) found that it reduced the toxicity (determined by mobility and phytoavailability) of trace metals in plants. 2) Animal manure can contain high levels of nutrients such as N, P and K (Moreno-Caselles et al., 2002). Kirchmann and Ewnetu (1998) found that co-composting with horse manure could reduce the concentration of large paraffin molecules by $80 \%$ in 110 days, as well as $93 \%$ of petroleum residues in 50 days. Cole (1998) reported that mature manure (six months) was efficient and reduced treatment time from the typical six months or more to two months or less for oily sludges (PHC in the engine oils molecular range). 3) Brewers' Spent Grain (BSG), which is the mass of wet grains remaining after the beer manufacturing process, is a fast-growing RFM in our region. The number of microbreweries has more than doubled (105 new) in the last seven years (AMBQ, 2018). The production of BSG for micro-breweries in Quebec is approximately $970000 \mathrm{~kg} \mathrm{year}^{-1}$. BSG is rich in nutrients and contains 77 to $81 \%$ water $\left(\mathrm{w} \mathrm{w}^{-1}\right.$ ) (Santos et al., 2003). Abioye (2011) suggests that BSG is a promising agent for the bioremediation of soil contaminated with PHC and metals. Research by Santos et al. (2003) shows that the BSG resulting from different types of beer within the same brewery was fairly homogenous, thus ensuring greater replicability.

In bioremediation, laboratory results do not always correspond with field observations since the dynamics of large-scale bioremediation systems are different. Key soil parameters (such as 
124 moisture, aeration, temperature, homogeneity, etc.) become more difficult to control with 125 increasing size, and bioremediation dynamics do not seem to follow a linear transfer in efficiency 126 from small to medium to large scale (Khan et al., 2015; Ko et al., 2007). Furthermore, the legal 127 regulations for industrial applications do not need to be respected in laboratory experiments. The 128 scaling up of experiments must respect the legal framework applicable to the region or go through 129 a process of application for approval, which can slow down technology transfer. In this study, we 130 worked in partnership with an industrial soil remediation operator (Akifer for the SolNeuf 131 treatment site) who projected to treat heavy PHC fractions (PHC molecules with more than 20 132 carbon atoms $\left(\mathrm{C}_{20}\right)$ ) on their platform. The remediation target for the contaminant chosen (engine 133 oil) was set to the province of Quebec's ' $\mathrm{C}$ ' criteria (commercial use, less than $3500 \mathrm{mg} \mathrm{kg}^{-1}$ for 134 the PHC molecules in the $\mathrm{C}_{10}-\mathrm{C}_{50}$ range), and was to be achieved within one treatment season in 135 pilot scale $\left(0.76 \mathrm{~m}^{3}\right)$ experimental units, using different local residual organic matter found close 136 to the treatment platform. We aimed to quantify if there was preferential degradation of some PHC 137 fractions among treatments. We sought to determine how the amendments changed the metabolic 138 activity of the soil's bacterial communities and if distinctive 'fingerprints' could be identified.

\section{Materials and methods}

\section{$140 \quad 2.1 \quad$ Soil preparation}

141 This experiment was conducted on a certified treatment platform for contaminated soils owned by 142 SolNeuf Inc., and operated by AKIFER Inc., located in Neuville, Quebec, Canada (46 $46^{\circ}$ '5.0352" $\left.143 \mathrm{~N}, 71^{\circ} 41^{\prime} 2.634^{\prime \prime} \mathrm{W}\right)$. The soil used was sandy $(98.4 \pm 0.3 \%$ sand, $2.5 \pm 0.2 \%$ gravel, $0.9 \pm 0.1 \%$ 144 silt and loam), with a $\mathrm{pH}$ of $6.4\left(1: 1\right.$, soil: $\left.\mathrm{H}_{2} \mathrm{O}\right)$. It contained less than $0.3 \%$ organic matter 145 (combustion) and $34.4 \mathrm{mg} \mathrm{kg}^{-1}$ phosphorus (P). The soil was free of PHC as measured by GC-FID 146 (Gas Chromatography with Flame Ionization Detector) according to the method MA. 400 - HYD. 147 1.1 (CEAEQ, 2016). In order to control the concentration and homogeneity of the contamination, 148 the initial soil was artificially contaminated with unused engine oil to $7500 \mathrm{mg} \mathrm{kg}^{-1}$ of $\mathrm{PHC}\left(\mathrm{C}_{10^{-}}\right.$ $149 \mathrm{C}_{50}$ ) and thoroughly mixed for $1 \mathrm{~h}$ by excavator. The oil was RUBIA LD 10W30, manufactured by 150 Total for diesel motors. The PHC concentrations were followed from June to November 2015. The 151 target for remediation was the Government of Quebec's ' $\mathrm{C}$ ' Criteria (less than $3500 \mathrm{mg} \mathrm{kg}^{-1}$ in the $152 \mathrm{C}_{10}-\mathrm{C}_{50}$ range) (Beaulieu, 2016).

\section{$153 \quad 2.2 \quad$ RFM soil amendments}

154 For the RFM materials, we defined as 'local' the ones that originated from a distance of $100 \mathrm{~km}$ 155 or less of the soil treatment platform. This action was guided by a circular economy framework 156 and the ITRC's Regulatory Guidance for Green and Sustainable Remediation to minimize the 157 project's carbon footprint by reducing fuel consumption associated with transport (ITRC, 2011). 158 A recycling and triage center located just 600 meters from the treatment platform was the first 159 location where RFM were sought out. Ramial chipped wood (RCW) of mixed origin (unspecified 160 mix of deciduous trees and conifers, excluding Thuja sp.) was chosen. RCW differs from regular 161 wood chips because it originates from branches less than $7 \mathrm{~cm}$ in diameter and not whole trunks 162 (stem wood) (Lemieux, 1986). The second closest available RFM was excess horse manure from 163 stables $8 \mathrm{~km}$ away (homogeneous mix of fresh to eight months old manure). The last RFM was 164 brewer's spent grain (BSG). Initially intended to be sourced $12 \mathrm{~km}$ away, the BSG used for the 
165 project had to be sourced $92 \mathrm{~km}$ away because of time constraints. The spent grain used in this

166 project was four days old and had been stored outdoors in barrels.

\section{$167 \quad 2.3 \quad$ Experimental design}

168 The four treatments used were: 1 - Ramial Chipped Wood (RCW-F), 2 - Brewer's Spent Grain 169 (BSG-F), 3 - Horse manure (MANR-F), and 4 - Fertilizer alone (FERT) (88.6\% calcium mononitrate $(27 \mathrm{~N}: 2.7 \mathrm{Mg}: 4.6 \mathrm{Ca})$ and $11.4 \%$ diammonium phosphate $(18 \mathrm{~N}: 46 \mathrm{P}: 0 \mathrm{~K})$ to achieve a $\mathrm{C}: \mathrm{N}: \mathrm{P}$ ratio of $100: 2.5: 0.5)$. This fertilizer dosage is the usual treatment at this treatment platform, and it was also added as a nutrient baseline to all other treatments (' $F$ '). Due to space and logistical constraints, no bins were tested without fertilizer. The organic amendments were added at a ratio of $30 \%$ by volume for each local organic amendment and were mixed for 10 minutes by excavator, followed by 10 minutes of hand-shovel mixing (see Fig S1 for design). For each treatment, three concrete cylinders $\left(0.76 \mathrm{~m}^{3}\right)$ were placed outdoor and filled with $760 \mathrm{~L}$ of the resulting mixtures of soil and amendments. The twelve cylinders were randomly distributed in a straight-line oriented southwest-northeast. Following the province of Quebec's regulations, the tops of the bins were covered with a thick plastic and a pulled-air system was connected to a perforated 2" PVC pipe placed $48 \mathrm{~cm}$ from the bottom of each bin (10\% below the center). The air was drawn at a rate of $1.5 \pm 0.26 \mathrm{~m}^{3} \mathrm{~h}^{-1}$ and passed through a biofilter prior to release to the atmosphere. The rate was set to be proportional to the airflow in large biopiles on this site. Finally, all water runoff was collected and sent for treatment at a registered facility. The targeted soil moisture concentration was set at $70 \%$ of field capacity. When the moisture levels dropped significantly below that target, watering events took place $(n=3)$.

\subsection{Sampling}

187

The concentrations of $\mathrm{C}_{10}-\mathrm{C}_{50}$ PHC in the soil were monitored three times over 5 months, on June 10, August 31 and November 2, 2015. On the first and last sampling dates, the $\mathrm{C}_{10}-\mathrm{C}_{50}$ PHC fractions were split into 6 smaller fractions $\left(\mathrm{C}_{10^{-}} \mathrm{C}_{16}, \mathrm{C}_{16^{-}} \mathrm{C}_{22}, \mathrm{C}_{22}-\mathrm{C}_{28}, \mathrm{C}_{28}-\mathrm{C}_{34}, \mathrm{C}_{34^{-}} \mathrm{C}_{40}\right.$, and $\mathrm{C}_{40^{-}}$ $\mathrm{C}_{50}$ ) to quantify if there was preferential fraction degradation. At each sampling event two new holes were drilled with a manual auger $(5 \mathrm{~cm}$ diameter). Samples were taken from $30 \mathrm{~cm}$ and 60 $\mathrm{cm}$ depths in the first hole, and from $60 \mathrm{~cm}$ and $90 \mathrm{~cm}$ depths in the second hole. These four samples were homogenized and sub-sampled for all analyses. Nutrient measurements were conducted from the first and last sampling events described above. For moisture readings, the soil was sampled eight times and was measured gravimetrically (oven dry). Gas measurements were taken from a tube linked to a perforated PVC pipe capped on both ends and placed in the center of each bin. Carbon dioxide $\left(\mathrm{CO}_{2}\right)$, oxygen $\left(\mathrm{O}_{2}\right)$, and volatile organic compounds (VOCs) were measured with a portable gas detector (Eagle model, RKI Instruments). The tube's end was equipped with a clamp, which was released to measure the gases present in the bins. Temperature loggers (Levelogger Gold model 3001, by Solinst) were placed inside the PVC pipes used for gas monitoring in each experimental unit. Temperature was recorded every hour throughout the experiment. The loggers were calibrated at the beginning of the experiment and the deviation between loggers did not exceed $0.3^{\circ} \mathrm{C}\left(0.14 \pm 0.03^{\circ} \mathrm{C}\right.$ (air) and $0.08 \pm 0.03^{\circ} \mathrm{C}$ (water)).

\section{$204 \quad 2.5 \quad$ Analytical methods}

205 The PHC fractions were measured by GCFID according to the MA. 400 - HYD. 1.1 method 206 (CEAEQ, 2016). Soil samples were first dried with acetone (CAS no 67-64-1) and then extracted 
207 with hexane (CAS no 110-54-3) using a 'paint mixer' type extraction system. Subsequently, silica 208 gel (60-200 mesh grade 62 (CAS no 112926-00-8), $\mathrm{SiO}_{2}$ ) was added to the extract to adsorb the 209 polar substances. Finally, the supernatant hexane was analyzed by GC-FID. The concentration of 210 hydrocarbons present in the sample was determined by comparing the total area of all peaks from $211 \mathrm{n}-\mathrm{C}_{10}$ to $\mathrm{n}-\mathrm{C}_{50}$ with the surfaces of the standards used to establish the calibration curve under the 212 same assay conditions (diesel standard solution altered to $50 \%$ at $5000 \mu \mathrm{g} \mathrm{ml}^{-1}$ ('Diesel fuel No. 213 2'), by Restek). The methodological limit of quantification was $100 \mathrm{mg} \mathrm{kg}^{-1}$ and PHC recovery 214 rates were all between 82 and 94\%.

215 The determination of ammoniacal nitrogen was a two-step process conducted according to method 216 MA 300-N 2.0 (CEAEQ, 2014a). The first step was an extraction in the presence of potassium 217 chloride (CAS no 7747-40-7). Secondly, the ammonium ion reacted with sodium salicylate (CAS 218 \#54-21-7), nitroferricyanide (CAS no 13755-38-9) and dichloroisocyanuric acid (CAS no 2893219 78-9) to form a blue alkaline complex with an absorbance at $660 \mathrm{~nm}$, which is proportional to the 220 concentration of ammoniacal nitrogen. Ammoniacal nitrogen recovery rates were between 95 and $96 \%$. Phosphorus concentrations were determined according to method MA. 300 - NTPT 2.0 (CEAEQ, 2014b). Nitrate and nitrite ions were analyzed in accordance with method MA. 300 Ions 1.3 (CEAEQ, 2014c). The soil was mixed with water in order to dissolve the extractable anions. For leached nitrates and nitrites, the extraction was done with the leaching buffer as specified in the Hazardous Materials Regulations and described in method MA. 100 - Lix.com. 1.1 (CEAEQ, 2012). Subsequently, anions are were separated by an ion exchange column using the following eluent solution: 0.0027 M sodium carbonate (CAS no 497-19-8) and $0.0003 \mathrm{M}$ sodium bicarbonate (CAS no 144-55-8)). The retention time differs for each anion, which makes it possible to identify and dose them. Nitrates and nitrites were measured using a conductivity sensor and the measured conductivity was proportional to the concentration of the anion in the sample. Recovery rates were between $97-104 \%$.

232 Total phosphorus was determined in two steps. First, an acid digestion with sulfuric acid (CAS no 233 7664-93-9), which transforms phosphorus into orthophosphate. Secondly, orthophosphate ions 234 were assayed by an automated system. The orthophosphate ion reacted with molybdate (CAS no 12054-85-2) and antimony (CAS no 28300-74-5) ions to form a phosphomolybdate complex. The

236 latter was reduced with ascorbic acid (CAS no 50-81-7) to trigger the appearance of molybdenum

237 blue, whose absorbance at $660 \mathrm{~nm}$ is proportional to the concentration of the orthophosphate ion.

238 The detection limit was $200 \mathrm{mg} \mathrm{kg}^{-1}$ and recovery rates were within $\pm 15 \%$.

239 Total organic carbon (TOC) was measured by combustion according to method MA. 310-CS 1.0 240 (CEAEQ, 2013) at $1360^{\circ} \mathrm{C}$ for a maximum of 600 seconds (oxygen at $30 \mathrm{lb} \mathrm{in}^{2}$ ). Recovery rates 241 were between 112-113\%. The water used for the preparation of reagents and standard solutions

242 was distilled or demineralized water. All samples were kept at $4^{\circ} \mathrm{C}$ until analysis (less than 14 243 days).

\section{$244 \quad 2.6$ Community-level physiological profiling}

245 The 96-well microplates contained 31 individual carbon sources from 6 classes (amine, amino 246 acids, carbohydrates, carboxylic acids, phenolic compounds and polymers) (replicated 3 times in 247 each plate) along with a clear tetrazolium dye, which gets irreversibly reduced to purple formazan 248 dye when the bacteria consume the carbon (Bochner, 1989). One plate was used for each treatment 
cylinder ( $\mathrm{n}=9$ carbon sources per treatment). A soil-aqueous solution was made according to methods previously described (Choi and Dobbs, 1999). All optical densities (OD) were brought below $0.350 \mathrm{~nm}(0.264 \pm 0.009 \mathrm{~nm})$ through dilutions to normalize the optical density at time zero. The well color development was monitored every day for 6 days by spectrophotometer $(590 \mathrm{~nm})$ and raw data was normalized by subtracting the control wells (water) present within each plate's three replicates. The result were interpreted by the rate of color change in the wells, the area under the curve and the functional richness as described in Choi \& Dobbs (1999) and Garland (1997). The average well color development (AWCD) was calculated with the following formula: AWCD $=\sum \frac{(\boldsymbol{C}-\boldsymbol{R})}{n}$, where $\mathrm{C}$ is color production, $\mathrm{R}$ is the absorbance of the control (water) and $\mathrm{n}$ is the number of substrates $(n=31)$. To independently estimate color development, a curve-integration (CI) approach was used. The area under the curve (the trapezoid area) was calculated as: $\sum_{i=1}^{n} \frac{\boldsymbol{v}_{i}+\boldsymbol{v}_{i-1}}{2} \times\left(\boldsymbol{t}_{\boldsymbol{i}}-\boldsymbol{t}_{\boldsymbol{i}-\mathbf{1}}\right)$ where $\mathrm{v}$ is optical density at time t. Functional richness is defined by the number of positive wells $\left(\mathrm{OD}_{\text {final }}-\mathrm{OD}_{\text {initial }}>0.25 \mathrm{~nm}\right)$.

\subsection{Statistical analysis}

Decreases in PHC concentrations, moisture levels, EcoPlates ${ }^{\mathrm{TM}}$ data, and temperature between treatments were assessed with a linear mixed-effects repeated measures model fitted by Restricted Maximum Likelihood (REML), performed with the nlme \{\} (Pinheiro et al., 2017) in R (R Core Team et al., 2016). Post-hoc multiple comparison analysis were performed with the Tukey HSD method (lsmeans \{\} (Lenth, 2016) and mltcompview \{\} (Hothorn et al., 2008)). Assumptions of normality and homoscedasticity were met for all mixed model tests. Gas readings $\left(\mathrm{O}_{2}, \mathrm{CO}_{2}, \mathrm{VOC}\right)$ were analyzed with the Kruskal-Wallis test by ranks for non-parametric data agricolae \{\} (Mendiburu, 2017). Multiple comparisons were corrected with Bonferroni for all parametric and non-parametric tests. Figures were built with ggplot 2\{\} (R Core Team et al., 2016; Wickham, 2009).

\section{Results}

\subsection{Soil properties}

In the first month, BSG-F temperatures in two bins spiked at least $14^{\circ} \mathrm{C}$ above the other bins. Overall, the maximum temperatures reached were $45^{\circ} \mathrm{C}, 31^{\circ} \mathrm{C}, 29^{\circ} \mathrm{C}$ and $28^{\circ} \mathrm{C}$ for BSG-F, MANRF, RCW-F and FERT respectively. There was variability between bins of the same treatment and between treatments, but for the first 90 days, the mean temperature across bins was $22.9 \pm 2.7^{\circ} \mathrm{C}$ $(\mathrm{n}=25920)$. Subsequently, the bins' internal temperatures gradually dropped with the advent of the fall season (Fig. 1A). At this point, BSG-F remained significantly higher than the other treatments (with the exception of the 10-day increment reported at 140 days) (mixed model, $p<$ 0.05). The addition of engine oil (Total Base Number: 10) raised the initial soil $\mathrm{pH}$ by around one unit, to approximately 7.4 across all treatments. Subsequently, all treatments remained stable with a pH between 7.2 and 7.6, except for the BSG, $(6.8 \pm 0.4$, after oil addition, and increased to $7.6 \pm$ 0.2 by the end of the experiment). Water requirements varied between treatments. To maintain soil moisture near $70 \%$ of field capacity, three watering events took place during the course of the experiment. FERT had little water-holding capacity and needed watering each time. RCW-F required watering during the first two events, but not the third. MANR-F remained within a desirable moisture range ( $70 \%$ of field capacity) for the duration of the experiment and did not 
290 require any additional watering. Finally, BSG-F did not require any watering either and it 291 contained the highest moisture levels of all treatments. There was a strong correlation between the 292 amount of moisture (\%) and the organic carbon content in the soil (excluding PHC-based carbon). 293 (Fig. 1B).

\section{$294 \quad 3.2 \quad$ Nutrient balance}

295

296

297

298

299

300

301

302

303

304

305

306

307

308

309

310

311

312

313

314

315

316

317

318

319

320

321

322

323

324

325

326

327

328

329

Raw brewer's spent grain (BSG) was the amendment richest in nitrogen whereas ramial chipped wood (RCW) contained the least nutrients (Table 1). All treatments experienced a sharp decline in available nitrogen $\left(\mathrm{NO}_{2}^{-}, \mathrm{NO}_{3}^{-}\right.$and $\left.\mathrm{NH}_{4}^{+}\right)$, which was likely assimilated by soil microorganisms, with the exception of BSG-F, where a sharp increase in $\mathrm{NH}_{3}$ and $\mathrm{NH}_{4}^{+}$was observed between June and November. Treatments all show relatively low total nitrogen loss $(<15 \%)$, except BSG-F that lost nearly $25 \%$. For FERT, an increase in total nitrogen was measured. Since there were no nitrogen inputs over the course of the project, this is probably linked to a heterogeneous distribution of the fertilizer in the soil.

\subsection{Engine oil decrease}

A sharp decrease in the first 82 days, followed by a plateau was observed for all treatments, except the BSG, which maintained a slower but constant reduction over the five-month experiment (Fig. 2A). There is little variability within each treatment for the initial PHC data before RFMs addition ( \pm 57 to $\pm 173 \mathrm{mg} \mathrm{kg}^{-1}$, which represents a variability range of 0.8 to $2.7 \%$ ), indicating a homogeneous initial distribution of the engine oil in the soil. However, PHC concentrations were different for all treatments at the start $(p<0.05)$, which is likely due to uneven dilution from the different RFMs since they were added on a volume basis and PHC concentrations are expressed on a mass basis (Table 1). MANR-F was significantly more effective at driving a $\mathrm{PHC}$ reduction (77 $\pm 3 \%$ reduction) in the soil than all other treatments (BSG-F: $38 \pm 11 \%$, RCW-F: $60 \pm 6 \%$, and FERT: $62 \pm 4 \%$ ) (mixed model, $p<0.05$ ). On August 31, while the platform's usual fertilizer treatment (FERT) was fluctuating around the Commercial \& Industrial sites' regulatory guideline (3500 mg kg$)^{-1}$ ), MANR-F was well below it and approaching the Residential \& Recreational guideline $\left(700 \mathrm{mg} \mathrm{kg}^{-1}\right)$ (Fig. 2A). The analysis of engine oil by fraction revealed the lightest $\left(\mathrm{C}_{10^{-}}\right.$ $\left.\mathrm{C}_{16}\right)$ and heaviest $\left(\mathrm{C}_{40} 0^{-} \mathrm{C}_{50}\right)$ fractions were either close to or below the detection limit $\left(100 \mathrm{mg} \mathrm{kg}^{-}\right.$ $\left.{ }^{1}\right)$ and were excluded from further analysis. The next lightest fraction $\left(\mathrm{C}_{16}-\mathrm{C}_{22}\right)$ decreased significantly more $(63 \pm 22 \%)$ than the rest of the fractions $\left(\mathrm{C}_{22}-\mathrm{C}_{28}, \mathrm{C}_{28}-\mathrm{C}_{34}, \mathrm{C}_{34}-\mathrm{C}_{40}\right)$, which were removed at equivalent rates $(42 \pm 17,39 \pm 16$ and $44 \pm 15 \%$, respectively), despite differences in molecular size (Fig. 2B).

\subsection{Outgassing}

There were notable differences in the gas emissions monitored among the different treatments, despite high variability within the data (Fig. 3). With a mean of $7.9 \pm 3.6 \%$, BSG-F contained significantly less $\mathrm{O}_{2}$ than the other treatments, which all showed averages between 18 and $19 \%(p$ $<0.05) . \mathrm{CO}_{2}$ emissions by FERT and BSG-F were always near the upper detection limit of the equipment (6000 ppm), while MANR-F was the treatment with the lowest mean emission (2695 $\pm 2871 \mathrm{ppm})(p<0.05)$. VOCs were very low in all treatments (means below $250 \mathrm{ppm}$ ), except for BSG-F (3636 \pm 3318 ppm), which released significantly more than all other treatments $(p<$ 
330 0.05). The VOCs emitted in this case could likely be methane from the breakdown of organics in 331 waterlogged pockets of the cylinder which had become anoxic.

\section{$332 \quad 3.5 \quad$ Community-level physiological profiling}

333 The global metabolic activity of the plates (AWCD) showed that the soils with amendments were more active than the FERT by the third day and by the fourth day, BSG-F had more AWCD than all others (Fig. 4A) (mixed model, $p<0.05$ ). All treatments followed a sigmoidal shape, presenting a standard bacterial growth curve. The curve-integration approach also revealed that FERT-F was less active than the soils amended with local RFM. There were differences in carbon usage between treatments. For example, BSG-F was able to use polymer carbon sources more effectively than the other treatments and FERT-F used carbohydrates less effectively than all other treatments (mixed model, $p<0.05$ ). Multiple significant differences were also noted within the usage of the carbohydrates, where bacteria in RCW-F were able to actively use more C sources, more rapidly than all other treatments. There was less functional richness in FERT (240 active wells out of 288) than in MANR-F (270), RCW-F (270) and BSG-F (273). Finally, the PCA indicates a clear separation between BSG-F and the other three treatments, which form over-lapping but clear clusters (Fig. 4B). This confirms the different soils' bacterial community's catabolic activity fingerprint.

\section{Discussion}

\subsection{CLPP and soil properties}

Community-level physiological profiling (CLPP) conducted with the Ecoplates ${ }^{\mathrm{TM}}$ indicated that the biological amendments increased the metabolic activity and functional richness of the soils compared to the fertilizer control (FERT). No well-defined links between PHC-degradation efficiency and Ecoplates-derived metabolic activity were observed. Nonetheless, there were clear clusters in the PCA defining the catabolic capabilities of the soils based on amendment. Microbial activity is optimal between 20 and $40^{\circ} \mathrm{C}$ for petroleum remediation and slows when soil temperatures drop close to $0{ }^{\circ} \mathrm{C}$ (Battelle and NFESC, 1996). In this project, overall higher temperatures were not linked to higher rates of contaminant removal. Other authors have found that temperature had a great influence on the reduction of petroleum concentrations (Van Gestel et al., 2003), or that higher temperatures could lead to increased volatilization (but unlikely with heavy PHC) (Namkoong et al., 2002). In our case, BSG-F exhibited the highest temperatures, but was the least effective at PHC-removal. This was most likely due to the heat generated during fermentation (anaerobic breakdown) of the BSG. Soil $\mathrm{pH}$ is influenced by microbes, and can also be influenced by their activity (Nwankwegu and Onwosi, 2017). Over the course of this experiment, $\mathrm{pH}$ remained stable in all treatments, except in the BSG-F. Other studies have reported $\mathrm{pH}$ variations in most treatments; this difference in our work could be linked to the soil's $\mathrm{pH}$ buffering capacity or the large-scale set-up, which has different dynamics than microcosms (Nwankwegu and Onwosi, 2017; Prince, 2015). Moisture is an important factor for bioremediation: concentrations too low inhibit microbial activity, and excessive moisture levels can promote hypoxic conditions that are less conducive to rapid biodegradation of PHC (Khan et al., 2004). A moisture content of 50 to $70 \%$ of field capacity is often cited as optimal (ATSDR,

370 1999; Khan et al., 2015). In the sandy soil used in the trials, 70\% of the field capacity corresponds

371 to about $15 \%$ moisture on a mass basis $\left(\mathrm{g} \mathrm{g}^{-1}\right)$. Field capacity varies with soil type and organic 
372 matter in soil can improve water retention (Brady and Weil, 1996a). The various local organic

373 amendments used in this project clearly demonstrated this point, with the strong correlation

374 between non-PHC carbon in the soil and moisture levels, and with the different watering

375 requirements of the treatments. FERT had virtually no organic matter and required moisture

376 addition throughout the project. RCW-F required watering the first two events, but not the third,

377 indicating that the wood had started to retain water in the soil. BSG-F retained moisture slightly

378 above levels for optimal degradation $\left(20 \pm 1.7 \%\left(\mathrm{~g} \mathrm{~g}^{-1}\right)\right.$ at the start), but the aspect of most concern

379 was that this high moisture was coupled with a fine particle and compact amendment structure

380 which limited air circulation in the bins, fostering hypoxic conditions which are not ideal for rapid

381 PHC degradation. Further, the BSG supplied soil microbes with an abundance of easily accessible

382 food which may have been easier to target than the engine oil. Finally, MANR was the optimal

383 RFM input for moisture since MANR-F did not require any watering throughout the project, while

384 maintaining values close to $70 \%$ field capacity. Reduction in soil management operations can be

385 advantageous in large-scale settings.

\section{$386 \quad 4.2$ Nitrogen balance and engine oil removal}

387 In this study, nitrogen came from two main sources: an inorganic fertilizer and the three RFMs

388 (soil nitrogen content was negligible). No nitrogen was added during the course of the study. We

389 had aimed to keep the soils under aerobic conditions where volatile forms of $\mathrm{N}$ are not normally

390 emitted, hence total nitrogen should have remained stable throughout the monitoring. It did, with

391 the exception of BSG-F where a nearly $25 \%$ drop in nitrogen occurred. Other than heterogeneous

392 distribution in soil which can skew the results, total nitrogen loss in soils may be related to leaching

393 of soluble forms (although bins were largely protected from rainfall) or a denitrification process

394 resulting in the formation of nitrogen gas and its loss to the atmosphere. This last process may

395 indicate conditions in soils that are too low in oxygen. The reduced forms of nitrogen ( $\mathrm{NH}_{4}^{+}$and

$396 \mathrm{NH}_{3}$ ) present in the BSG-F soil in November support the presence of sub-optimal oxygen levels

397 since these reduced forms of nitrogen are usually observed when the soil is deficient in oxygen.

398 Whereas, when the soil is well aerated, nitrogen is found in oxidized forms such as nitrate and

399 nitrite (Brady and Weil, 1996b). There was an initial input of ammonium as diammonium

400 phosphate in the inorganic fertilizer, but this was not detected in the BSG bins at the beginning of

401 the experiment. The concentrations detected in November were likely mineralized from the

402 organic matter in the amendment and remained in this form due to lack of oxygen for conversion

403 to oxidized forms $\left(\mathrm{NO}_{3}{ }^{-}\right.$and $\left.\mathrm{NO}_{2}{ }^{-}\right)$by the nitrification process. Reduced forms of nitrogen are

404 most prevalent under hypoxic soil conditions (Britto and Kronzucker, 2002) and effective aliphatic

405 PHC-degradation usually occurs under aerobic conditions (Khan et al., 2004).

406 Larger PHC molecules were expected to be biodegraded at slower rates than the lighter ones, but

407 this was not generally the case in our study (Battelle and NFESC, 1996, Khan et al., 2004). The

$408 \mathrm{C}_{16}-\mathrm{C}_{22}$ fraction was indeed removed faster than the other fractions monitored, but the decrease of

409 the other three fractions (between $\mathrm{C}_{22}$ and $\left.\mathrm{C}_{40}\right)$ was statistically equivalent $(p>0.05)$. PHC can

410 move out of soil through volatilization, but other authors found mainly fractions below 12 to 16

411 carbons to be volatile while heavier compounds were mainly biodegraded (Namkoong et al., 2002,

412 Gallego et al., 2010). Bacteria usually reduce PHC molecules down to $\mathrm{CO}_{2}$ (Brady and Weil,

413 1996c). After 82 days of the different treatments, MANR-R had significantly decreased PHC

414 concentrations and was approaching the Residential and Recreational guideline ( $\left.700 \mathrm{mg} \mathrm{kg}^{-1}\right)$,

415 while the LTU's usual FERT treatment was fluctuating around the Commercial and Industrial

Peer] reviewing PDF | (2019:02:35072:1:0:NEW 26 Jun 2019) 
416 guideline (3500 mg kg-1) of the Quebec government regulations. From this point on to the end of 417 the experiments all treatments plateaued, and little degradation took place in the last 65 days. Since 418 varying levels of carbon from the PHC remained in the soil, it would be possible to optimize the 419 treatments to stimulate degradation beyond the plateaus. This could be done through better control

420

421

422

423

424

425

426

427

428

429

430

431

432

433

434

435

436

437

438

439

440

441

442

443

444

445

446

447

448

449

450

451

452

453

454

455

456

457

458

459 over parameters such as aeration, moisture and nutrients, and using known correlations for estimating petroleum biodegradation rates in soils, which are especially useful for scaling-up experiments (Khan et al., 2015).

BSG-F did not exhibit the same plateau but was far less effective than the other treatments for engine oil removal $(38 \pm 11 \%)$. Other authors have found BSG to be an effective soil amendment. In a phytoremediation experiment using the plant Jatropha curcas, Agamuthu et al. (2010) found that when BSG was added to a soil contaminated with $2.5 \%$ and $1 \%$ of lubricating oil, the degradation rates of the PHCs were $89.6 \%$ to $96.6 \%$ respectively. Oruru (2014) demonstrated not only the efficiency but also the sustainability of BSG as an amendment to treat diesel-contaminated soil. The reduced efficiency of the BSG-F in this study appears to be linked to the soil structure and excess moisture which restricted aeration. Despite its lower PHC-removal performance in this project, the application of BSG could be further considered for the remediation of soils with low nutrients and low water retention capacities, as long as aerobic conditions are maintained to minimize nitrogen loss and VOC output. Currently, farmers supplement their animals' regular feed with BSG, but rapid disposable is primordial for breweries because it ferments rapidly causing serious odor problems. This leads many city-based breweries to send their BSG to the landfill (Santos et al., 2003).

RCW-F was equivalent to FERT for PHC-removal and its measured contributions within this project are limited to improvements of soil parameters (moisture and microbial activity). Horse manure (MANR-F) was unequivocally the most successful soil amendment in this project. It led to the most PHC-reduction in the shortest time period. From a soil clean-up facility's perspective, this represents a faster turnaround of the soil and potential increases in profitability. MANR-F maintained adequate moisture and oxygen levels, while releasing the least amount of $\mathrm{CO}_{2}$, which is interesting in a global climate change context. The bacterial degradation of $\mathrm{PHC}$ emits $\mathrm{CO}_{2}$ and since the most PHC-removal took place in this treatment, it should have released more than the rest. Since it was not the case, we hypothesized a form of carbon sequestration in the microbial biomass, but this was not tested further.

\subsection{Cost of RFM and opportunities for circular economy?}

Within the scope of this project, horse manure (MANR) was available nearby and free of cost, but in other regions such manure may be sold at a higher price or used directly on adjacent farmlands, potentially reducing the application of our results to some regions. Ramial chipped wood (RCW) did not significantly increase remediation speed compared to fertilizer alone, but it promoted long term moisture retention, which can alleviate the management of biopiles through reduced watering needs. Brewer's spent grain (BSG) led to less PHC removal than the LTU's usual fertilizer treatment by limiting aeration due to excess moisture. In retrospect, the addition of $30 \% \mathrm{BSG}$ for this soil was excessive. We hypothesize that a smaller proportion of the dense and nutritious BSG, coupled with the addition of a bulking agent such as RCW could create favorable PHC remediation conditions at an advantageous cost. We conclude that there is no one-size-fits-all approach for the use of RFMs, and each remediation site will need to evaluate the RFMs available in their respective region.

Peer) reviewing PDF | (2019:02:35072:1:0:NEW 26 Jun 2019) 
460 In their Vision 2050 project, the World Business Council for Sustainable Development envisions 461 making the concept of waste obsolete as a normal business practice (WBCSD, 2010). This research 462 highlights a particularly interesting opportunity for soil treatment industries to actively participate 463 in this vision, by up-cycling degraded 'waste soil' through remediation and introducing it into a 464 circular economy loop. Further, RFM are present across the globe and can offer low-cost amendments to boost remediation efficiency while reducing treatment time.

\section{Conclusion}

467 Soil remediation industries can benefit from the addition of RFM in their operations, while 468 diverting RFMs from landfill, thereby contributing to waste diversion objectives set by European

469

470

471

472

473

474

475

476

477

478

479

480

481

482

483

484

485

486

487

488

489

490

491

492

493

494

495

496

497 and North American governing agencies. Each locality has regulations to limit the quantity of material that can be incorporated into contaminated soil, to avoid excessive dilution. Overall, RFM's main functions are improving moisture retention and soil structure, contributing nutrients and a greater diversity of microorganisms, and to enhance the growth matrix for microbial life in the soil, which can, in some cases, enhance PHC remediation as compared to fertilizers alone. These conclusions are unsurprising in the sense that adding organic matter to contaminated soil has been shown to foster bioremediation in the past, but we view the process undertaken in this project as another step towards more partnerships between academia and industry, in a manner that incorporates considerations of the broader environmental impacts of bioremediation work. The circular economy objective of reducing pollution and waste as much as possible served as a guiding principle to sourcing the three residual fertilizing matter (RFM) amendments within 100 $\mathrm{km}$ of the study site. Due to performance pressures, inorganic fertilizer use was maintained in the scope of this project, but future work should include the exploration of RFMs and processes which may allow for a move away from this traditional approach, which requires resources that are synthesized by high-energy processes and sourced from non-renewable resources (such as P). Overall, choice of the RFM treatment should be made considering multiple factors such as treatment effects, cost, time, accessibility by users, and sustainable supplying, to fall into the concept of a circular economy.

\section{Data availability statement}

All relevant data are within the paper.

\section{Conflict of Interest}

The authors declare that the research was conducted in the absence of any commercial or financial relationships that could be construed as a potential conflict of interest.

\section{Author contributions}

Designed the experiments and provided expertise on the design: KR, ML, SM, MA. Performed the experiments: KR, ML. Data was analyzed by KR. Wrote the paper: KR, MA. All authors have edited and given approval to the final version of the manuscript. 


\section{Funding}

499 Canada Research Chair in Global Change Ecotoxicology to MA and NSERC CREATE Mine of 500 Knowledge program to KR. Akifer and SolNeuf provided land space, PHC analysis expenses, and 501 in-kind: specialists, machinery, fertilizers and logistical support.

\section{$50210 \quad$ Acknowledgements}

503 A warm thank you to Nicolas Gruyer who provided resources and expertise for Ecoplates ${ }^{\mathrm{TM}}$. Thank 504 you Pierre Yves Cardon for your invaluable help with the Ecoplates work. Thank you to À la Fût 505 microbrewery for providing the BSG and helping with the logistics around its transport. Thank 506 you to Stéphane Lambert and Martine Sanchez for welcoming this project on your platform. And 507 last but not least, thank you to Yves Tourangeau for your enthusiastic dedication to the project and 508 strong field work! 
$50911 \quad$ References

510 Abioye, P.O., 2011. Biological Remediation of Hydrocarbon and Heavy Metals Contaminated

511

512

513

514

515

516

517

518

519

520

521

522

523

524

525

526

527

528

529

530

531

532

533

534

535

536

537

538

539

540

541

542

543

Soil, in: Pascucci, Ms.S. (Ed.), Soil Contamination. InTech, pp. 127-142.

doi: $10.5772 / 24938$

Agamuthu, P., Abioye, O.P., Aziz, A.A., 2010. Phytoremediation of soil contaminated with used lubricating oil using Jatropha curcas. J. Hazard. Mater. 179, 891-894.

doi:10.1016/j.jhazmat.2010.03.088

AMBQ, 2018. Portrait de l'industrie brassicole au Québec [WWW Document]. doi:http://www.ambq.ca/mod/file/ContentDoc/2b44928ae11fb9384c4cf38708677c48.pdf

ATSDR, 1999. Overview of Total Petroleum Hydrocarbons, in: Todd, G.D., Chessin, R.L., Colman, J. (Eds.), Toxicological Profile for Total Petroleum Hydrocarbons. Agency for Toxic Substances and Disease Registry, U.S. DEPARTMENT OF HEALTH AND HUMAN SERVICES, Atlanta.

Battelle, NFESC, 1996. Biopile Design and Construction Manual. Technical Memorandum TM2189-ENV. Environmental Restoration Department, United States Government \& Naval Facilities Engineering Service Center, Columbus, Ohio 43201-5263 \& Port Hueneme, California 93043-4301.

Beaulieu, M., 2016. Guide d'intervention - Protection des sols et réhabilitation des terrains contaminés, Ministère du Développement durable, de l'Environnement et de la Lutte contre les changements climatiques.

Biolog, 2018. Microbial community analysis [WWW Document]. EcoPlate TM. doi:10.1046/j.1462-2920.2002.t01-2-00257.x

Bochner, B.R., 1989. Sleuthing out bacterial identities. Nature 339, 157-158. doi:10.1038/339157a0

Bradley, R.L., Shipley, B., Beaulieu, C., 2006. Refining numerical approaches for analyzing soil microbial community catabolic profiles based on carbon source utilization patterns. Soil Biol. Biochem. 38, 629-632. doi:10.1016/j.soilbio.2005.07.002

Brady, N.C., Weil, R.R., 1996a. Soil Organic Matter, in: The Nature and Properties of Soils. Prentice Hall International Editions, Upper Saddle River, New-Jersey, pp. 361-399.

Brady, N.C., Weil, R.R., 1996b. The soils around us, in: The Nature and Properties of Soils. Prentice Hall International Editions, Upper Saddle River, New-Jersey, pp. 1-24.

Brady, N.C., Weil, R.R., 1996c. Soils and chemical pollution, in: The Nature and Properties of Soils. Prentice Hall International Editions, Upper Saddle River, New-Jersey, pp. 601-629.

Britto, D.T., Kronzucker, H.J., 2002. NH4+ toxicity in higher plants: a critical review. J. Plant Physiol. 159, 567-584. doi:10.1078/0176-1617-0774

Peer) reviewing PDF | (2019:02:35072:1:0:NEW 26 Jun 2019) 
544

545

546

547

548

549

550

551

552

553

554

555

556

557

558

559

560

561

562

563

564

565

566

567

568

569

570

571

572

573

574

575

576

577

578

579

580

CEAEQ, 2016. Détermination des hydrocarbures pétroliers (C10-C50) : dosage par chromatographie en phase gazeuse couplée à un détecteur à ionisation de flamme, MA. 400 - HYD. 1.1. Centre d'expertise en analyse environnementale du Québec. Ministère du Développement durable, de l'Environnement, de la Faune et des Parcs du Québec, p. 17.

CEAEQ, 2014a. Détermination de l'azote ammoniacal : méthode colorimétrique automatisée avec le salicylate de sodium, MA. 300- N 2.0. Centre d'expertise en analyse environnementale du Québec. Ministère du Développement durable, de l'Environnement, de la Faune et des Parcs du Québec, Québec, p. 14.

CEAEQ, 2014b. Détermination de l'azote total Kjeldahl et du phosphore total : digestion acide méthode colorimétrique automatisée, MA. 300 - NTPT 2.0. Centre d'expertise en analyse environnementale du Québec. Ministère du Développement durable, de l'Environnement, de la Faune et des Parcs du Québec, Québec, p. 16.

CEAEQ, 2014c. Détermination des anions : méthode par chromatographie ionique, MA. 300 Ions 1.3. Centre d'expertise en analyse environnementale du Québec. Ministère du Développement durable, de l'Environnement, de la Faune et des Parcs du Québec, Québec, p. 18.

CEAEQ, 2013. Détermination du carbone et du soufre : méthode par combustion et dosage par spectrophotométrie infrarouge, MA. 310-CS 1.0,. Centre d'expertise en analyse environnementale du Québec. Ministère du Développement durable, de l'Environnement, de la Faune et des Parcs du Québec, Québec, pp. 1-8.

CEAEQ, 2012. Protocole de lixiviation pour les espèces inorganiques, MA. 100 - Lix.com.1.1. Centre d'expertise en analyse environnementale du Québec. Ministère du Développement durable, de 1'Environnement, de la Faune et des Parcs du Québec, Québec, p. 17.

CEC, 2017. Characterization and Management of Organic Waste in North AmericaFoundational Report. Commission for Environmental Cooperation, Montréal, Canada.

Choi, K.H., Dobbs, F.C., 1999. Comparison of two kinds of Biolog microplates (GN and ECO) in their ability to distinguish among aquatic microbial communities. J. Microbiol. Methods 36, 203-213. doi:10.1016/S0167-7012(99)00034-2

Cole, M.A., 1998. An Analysis of Composting as an Environmental Remediation Technology, EPA530-R-9th ed, United States Environmental Protection Agency (US EPA). Solid Waste and Emergency Response. doi:10.1016/S0956-053X(02)00035-1

Daneshgar, S., Callegari, A., Capodaglio, A., Vaccari, D., 2018. The Potential Phosphorus Crisis: Resource Conservation and Possible Escape Technologies: A Review. Resources 7, 37. doi:10.3390/resources 7020037

Environment Canada, 2014. Municipal Solid Waste and Greenhouse Gases [WWW Document]. URL http://www.ec.gc.ca/gdd-mw/default.asp?lang=En\&n=6f92e701-1 (accessed 5.19.16).

European Commission, 2010. Being wise with waste: the EU's approach to waste management.

Peer) reviewing PDF | (2019:02:35072:1:0:NEW 26 Jun 2019) 
Publ. Off. Eur. Union 20. doi:10.2779/93543

582

583

584

585

586

587

588

589

590

591

592

593

594

595

596

597

598

599

600

601

602

603

604

605

606

607

608

609

610

611

612

613

614 615

Garland, J.L., 1997. Analysis and interpretation of community level physiological profiles in microbial ecology. FEMS Microbiol. Ecol. 24, 289-300.

Guidi, W., Kadri, H., Labrecque, M., 2012. Establishment techniques to using willow for phytoremediation on a former oil refinery in southern Quebec : achievements and constraints. Chem. Ecol. 28, 37-41.

Hattab, N., Motelica-Heino, M., Faure, O., Bouchardon, J.-L., 2015. Effect of fresh and mature organic amendments on the phytoremediation of technosols contaminated with high concentrations of trace elements. J. Environ. Manage. 159, 37-47. doi:10.1016/j.jenvman.2015.05.012

Hothorn, T., Bretz, F., Westfall, P., 2008. Simultaneous Inference in General Parametric Models $50,346-363$.

Hupe, K., Luth, J.C., Heerenklage, J., Stegmann, R., 1996. Enhancement of the biological degradation of contaminated soils by compost addition. Sci. Compost. 6, 913-923.

ITRC, 2011. Technical / Regulatory Guidance Green and Sustainable Remediation : A Practical Framework. Washington DC.

Ivshina, I.B., Kuyukina, M.S., Krivoruchko, A. V, Elkin, A. a, Makarov, S.O., Cunningham, C.J., Peshkur, T. a, Atlas, R.M., Philp, J.C., 2015. Oil spill problems and sustainable response strategies through new technologies. Environ. Sci. Process. Impacts 17, 1201-19. doi:10.1039/c5em00070j

Jones, D.L., Hill, P.W., Smith, A.R., Farrell, M., Ge, T., Banning, N.C., Murphy, D. V., 2018. Role of substrate supply on microbial carbon use efficiency and its role in interpreting soil microbial community-level physiological profiles (CLPP). Soil Biol. Biochem. 123, 1-6. doi:10.1016/j.soilbio.2018.04.014

Juwarkar, A.A., Singh, S.K., Mudhoo, A., 2010. A comprehensive overview of elements in bioremediation. Rev. Environ. Sci. Bio/Technology 9, 215-288. doi:10.1007/s11157-0109215-6

Kauppi, S., Sinkkonen, A., Romantschuk, M., 2011. Enhancing bioremediation of diesel-fuelcontaminated soil in a boreal climate: Comparison of biostimulation and bioaugmentation. Int. Biodeterior. Biodegrad. 65, 359-368. doi:10.1016/j.ibiod.2010.10.011

Khan, A.A., Zytner, R.G., Feng, Z., 2015. Establishing Correlations and Scale-Up Factor for Estimating the Petroleum Biodegradation Rate in Soil. Bioremediat. J. 19, 32-46. doi:10.1080/10889868.2014.933173

Khan, F.I., Husain, T., Hejazi, R., 2004. An overview and analysis of site remediation technologies. J. Environ. Manage. 71, 95-122. doi:10.1016/j.jenvman.2004.02.003 
616 Kirchmann, H., Ewnetu, W., 1998. Biodegradation of petroleum-based oil wastes through

617 composting. Biodegradation 9, 151-156. doi:10.1023/A:1008355825404

618 Ko, I., Kim, K.-W., Lee, C.-H., Lee, K.-P., 2007. Effect of scale-up and seasonal variation on

619 biokinetics in the enhanced bioremediation of petroleum hydrocarbon-contaminated soil.

620 Biotechnol. Bioprocess Eng. 12, 531-541.

621 Larose, M., Hébert, M., Plante, J., 2014. Bilan 2012 du recyclage des matières résiduelles

622 fertilisantes. Ministère du Développement durable, de l'Environnement, de la Faune et des

623 Parcs, Direction des matières résiduelles et des lieux contaminés, Bibliothèque et Archives

624 nationales du Québec, pp. 1-40.

625

626

627

628

629

630

631

632

633

634

635

636

637

638

639

640

641

642

643

644

645

646

647

648

649

Lemieux, G., 1986. Le bois raméal et les mécanismes de fertilité du sol, in: Le Groupe de Coordination sur les Bois Raméaux (Ed.), Colloque Sur Les Amendements Des Sols: Perspectives d'avenir. Université Laval, Département des Sciences du Bois et de la Forêt, Saint-Hyacinthe, p. 21. doi:ISBN 2-550-21338-1

Lenth, R. V., 2016. Least-Squares Means: The R Package 1smeans. J. Stat. Softw. 69, 1-33. doi:10.18637/jss.v069.i01

Lou, X.F., Nair, J., 2009. The impact of landfilling and composting on greenhouse gas emissions - A review. Bioresour. Technol. 100, 3792-3798. doi:10.1016/j.biortech.2008.12.006

Margesin, R., Schinner, F., 1997. Efficiency of indigenous and inoculated cold-adapted soil microorganisms for biodegradation of diesel oil in alpine soils. Appl. Environ. Microbiol. $63,2660-2664$.

Mendiburu, F. de, 2017. Statistical Procedures for Agricultural Research.

Moreno-Caselles, J., Moral, R., Perez-Murcia, M., Perez-Espinosa, A., Rufete, B., 2002. Nutrient value of animal manures in front of environmental hazards. Commun. Soil Sci. Plant Anal. 33, 3023-3032. doi:10.1081/CSS-120014499

Namkoong, W., Hwang, E.-Y., Park, J.-S., Choi, J.-Y., 2002. Bioremediation of dieselcontaminated soil with composting. Environ. Pollut. 119, 23-31.

Nwankwegu, A.S., Onwosi, C.O., 2017. Bioremediation of gasoline contaminated agricultural soil by bioaugmentation. Environ. Technol. Innov. 7, 1-11. doi:10.1016/j.eti.2016.11.003

Nwankwegu, A.S., Orji, M.U., Onwosi, C.O., 2016. Studies on organic and in-organic biostimulants in bioremediation of diesel-contaminated arable soil. Chemosphere 162, 148156. doi:10.1016/j.chemosphere.2016.07.074

Onwosi, C.O., Odibo, F.J.C., Enebechi, C.K., Nwankwegu, A.S., Ikele, A.I., Okeh, O.C., 2017. Bioremediation of Diesel-contaminated Soil by Composting with Locally Generated Bulking Agents. Soil Sediment Contam. 26, 438-456. doi:10.1080/15320383.2017.1348337

650 Oruru, J.A., 2014. Is the use of Brewery Spent Grain in Bioremediation of Diesel Contaminated 
651

652

653

654

655

656

657

658

659

660

661

662

663

664

665

666

667

668

669

670

671

672

673

674

675

676

677

678

679

680

681

682

683

Soil Sustainable? University of Sunderland.

Pinheiro, J., Bates, D., DebRoy, S., Sarkar, D., R_Core_Team, 2017. nlme: Linear and Nonlinear Mixed Effects Models.

Prince, R.C., 2015. Introduction: Mesocosms and Microcosms, in: McGenity, T., Timmis, K., Nogales, B. (Eds.), Hydrocarbon and Lipid Microbiology Protocols. Springer Protocols Handbooks, Berlin, Heidelberg, pp. 1-13. doi:10.1007/8623_2015_173

R Core Team, R Development Core Team, R Core Team, 2016. R: A language and environment for statistical computing.

Rafiqul, I., Weber, C., Lehmann, B., Voss, A., 2005. Energy efficiency improvements in ammonia production - Perspectives and uncertainties. Energy 30, 2487-2504. doi:10.1016/j.energy.2004.12.004

Santos, M., Jiménez, J.J., Bartolomé, B., Gómez-Cordovés, C., Del Nozal, M.J., 2003. Variability of brewer's spent grain within a brewery. Food Chem. 80, 17-21. doi:10.1016/S0308-8146(02)00229-7

Sauvé, S., Bernard, S., Sloan, P., 2015. Environmental sciences, sustainable development and circular economy: Alternative concepts for trans-disciplinary research. Environ. Dev. 1-9. doi:10.1016/j.envdev.2015.09.002

Sauvé, S., Normandin, D., Mcdonald, M., 2016. L'économie circulaire : Une transition incontournable. Les Presses de l’Université de Montréal, Montréal.

Schulten, H.R., Schnitzer, M., 1997. The chemistry of soil organic nitrogen: A review. Biol. Fertil. Soils 26, 1-15. doi:10.1007/s003740050335

Van Gestel, K., Mergaert, J., Swings, J., Coosemans, J., Ryckeboer, J., 2003. Bioremediation of diesel oil-contaminated soil by composting with biowaste. Environ. Pollut. 125, 361-368. doi:10.1016/S0269-7491(03)00109-X

WBCSD, 2010. Vision 2050: The new agenda for business. World Business Council for Sustainable Development, Atar Roto Presse SA, Switzerland.

Wickham, H., 2009. ggplot2: Elegant Graphics for Data Analysis.

Zubillaga, M.S., Bressan, E., Lavado, R.S., 2012. Effects of Phytoremediation and Application of Organic Amendment on the Mobility of Heavy Metals in a Polluted Soil Profile. Int. J. Phytoremediation 14, 212-220. doi:10.1080/15226514.2011.587848 
Figure 1

Soil temperature and moisture readings.

A) Mean temperature in the center of the treatment bins in 10-day increments $(n=720)$. Error bars are SD. (B) Correlation ( $R=0.893$ ) between soil carbon and moisture $(\%)$ in the experimental bins from June, September and November data. The carbon contents attributable to PHC concentrations were removed, as they do not contribute to water retention in the soil.
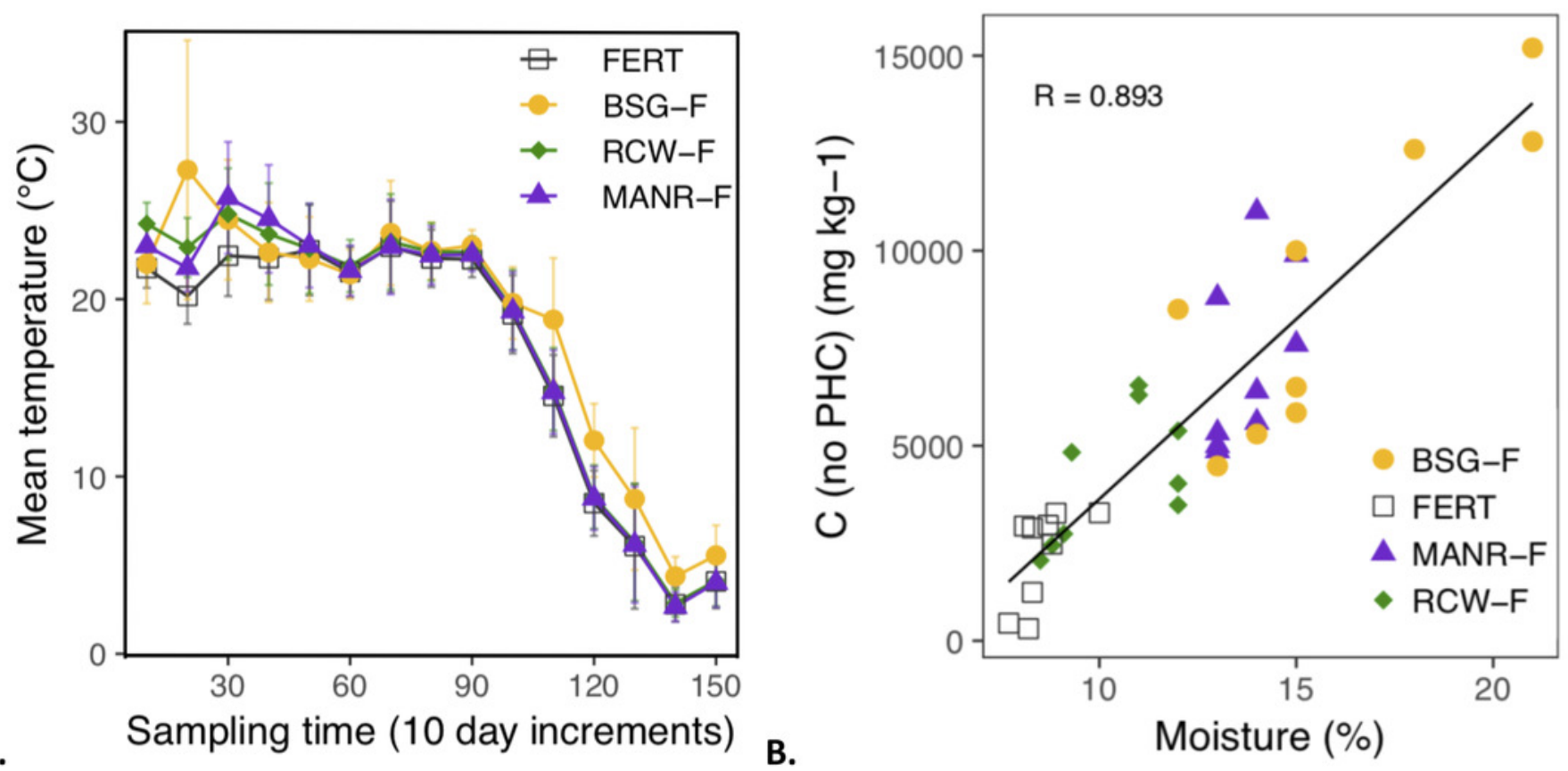


\section{Figure 2}

Petroleum hydrocarbon concentrations.

(A) Concentrations of engine oil fraction $C_{10}$ to $C_{50}$ over 147 days. The lines at 3500 and 700 $\mathrm{mg} \mathrm{kg}^{-1}$ indicate the Quebec environmental guidelines for Commercial \& Industrial sites (' $\mathrm{C}$ ') and Residential \& Recreational sites ('B') respectively (Beaulieu, 2016). (B) Concentrations of the six petroleum hydrocarbon fractions monitored in the soil. The dotted lines represent the last sampling event (November). Mean loss compares the percent decreases in the different fractions. The rank is Tukey HSD (Bonferroni correction applied for multiple comparisons, after a mixed model analysis $(p<0.05))$. For both figures, reported errors are standard deviation (SD, $n=3$ ).

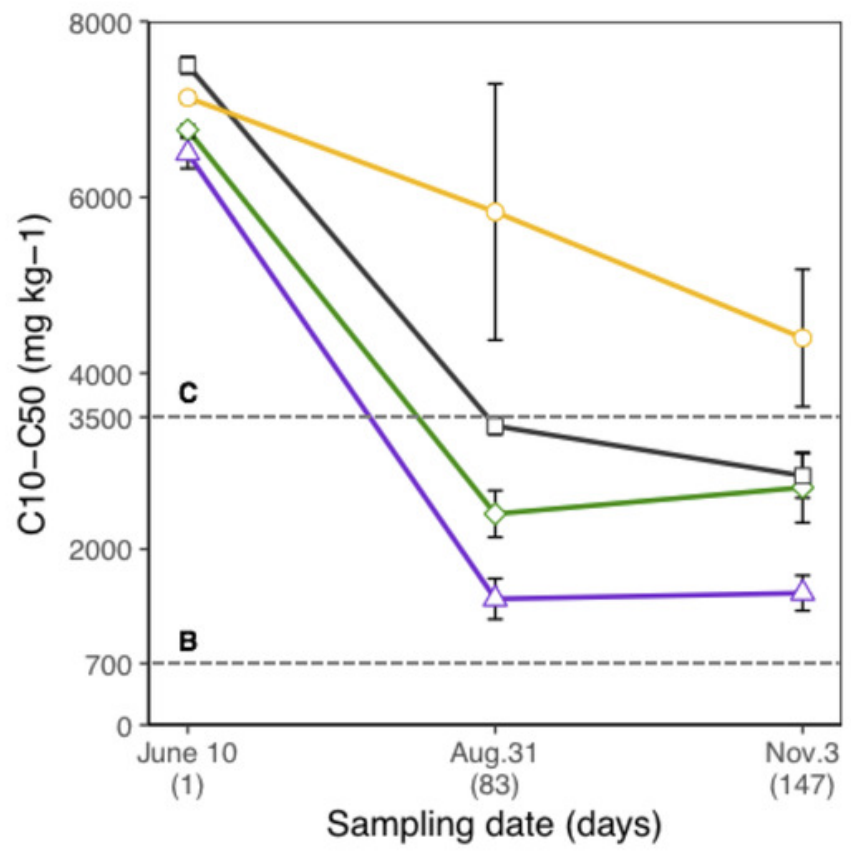

A.

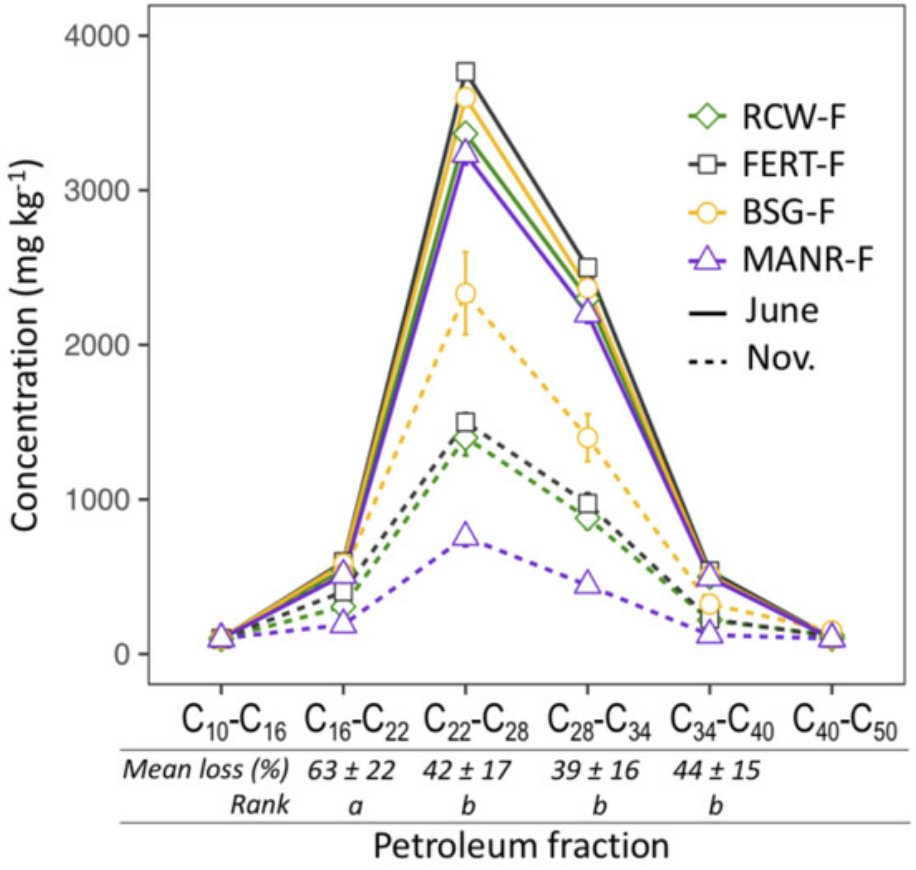

B. 
Figure 3

Gas concentrations in the center of the treatment bins measured seven times over 145 days.

(A) Oxygen (\%). (B) Carbon dioxide (ppm). (C) Volatile organic compounds (ppm). Error bars represent SD. Lower case letters denote statistical ranking (Kruskal-Wallis, $p<0.05$, Bonferroni correction applied for multiple comparisons. $n=21$ ).
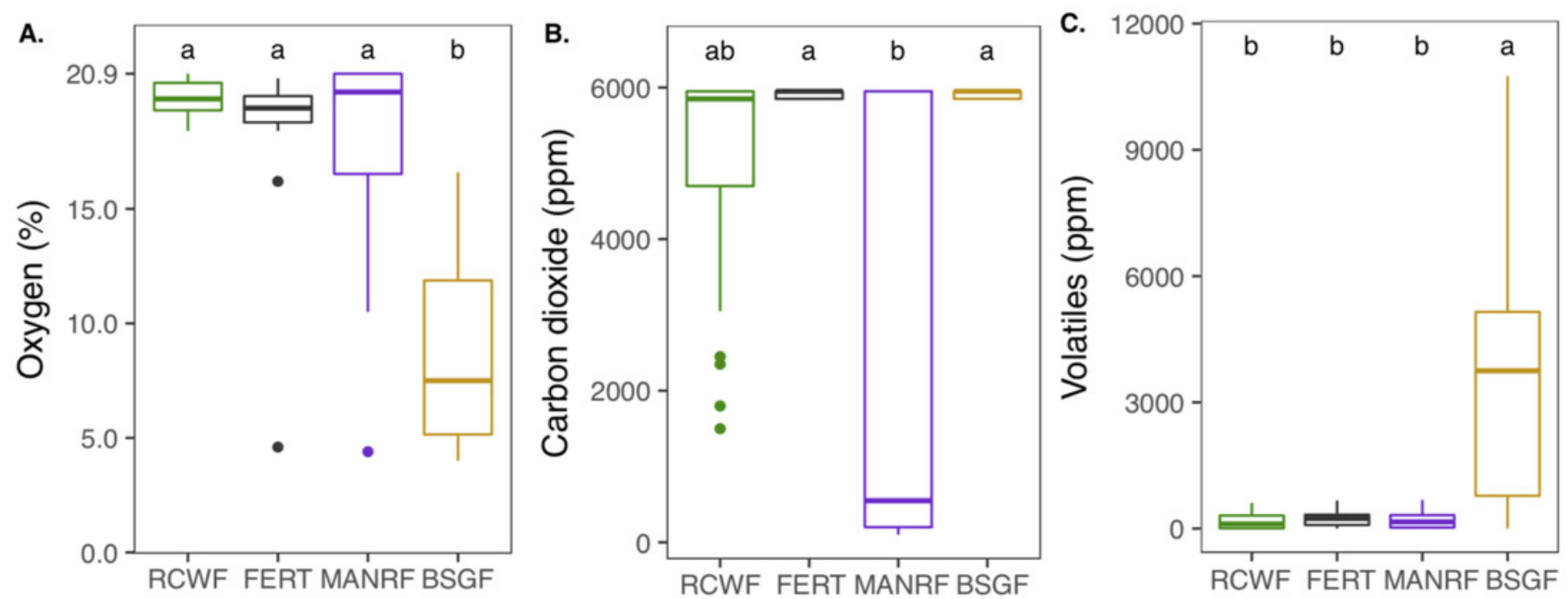
Figure 4

Ecoplate results.

(A) Average well color development (AWCD) (nm) over six days for soil from the four treatments. Error bars represent standard deviation. (B) PCA: Principal component analysis of the consumption of the 31 carbon sources in relation to the four treatments.

A.

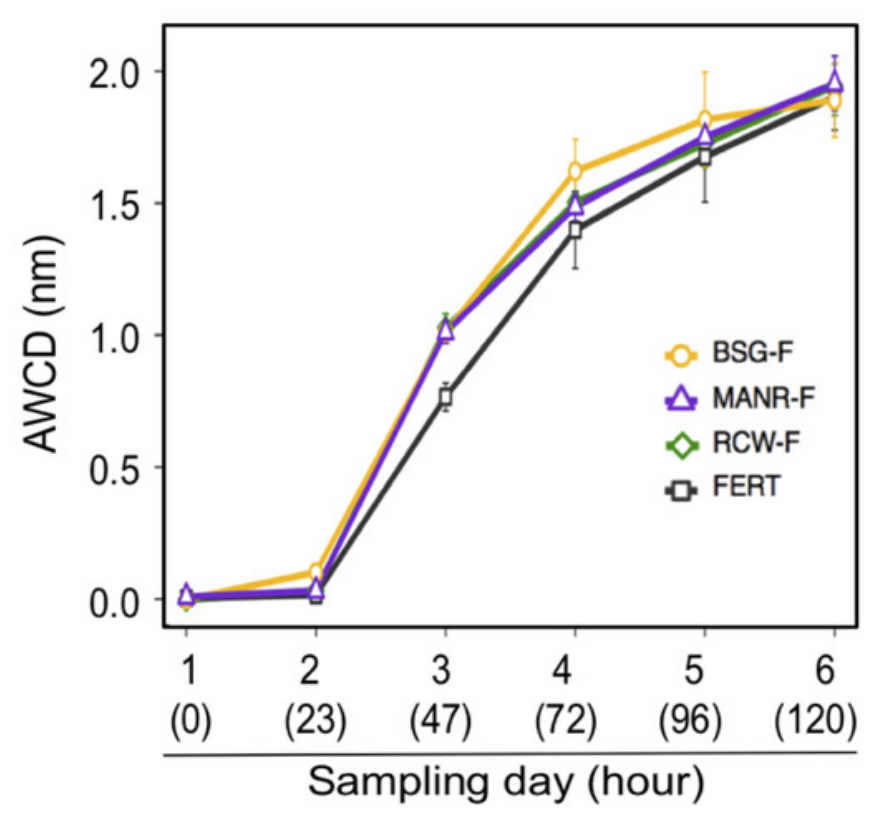

B.

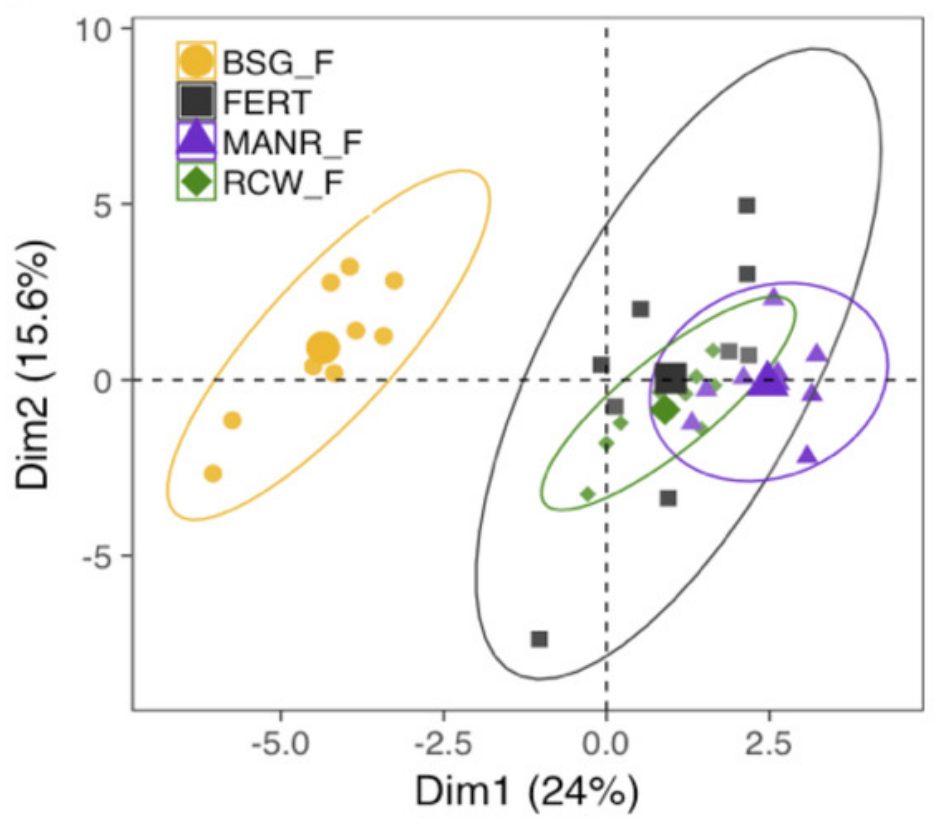




\section{Table $\mathbf{1}$ (on next page)}

Nutrient and organic matter content in raw amendments prior to incorporation in soil as well as measurements in the soil matrix at the beginning (June) and end of the experiment (November).

TOC stands for total organic carbon (values \pm SD). There is low variability within the treatments' initial PHC concentrations and they are statistically different from each other. Reduction presents the percent PHC removed and the lowercase letters denote statistical rank (mixed model, $p<0.05$ ). 
RAW LOCAL ORGANIC AMMENDMENTS

\begin{tabular}{lccccccc}
\hline & Analyte & $\mathbf{N H}_{3-4}$ & Total N & Total P & Total K & Org. matter & C:N \\
Source material & units & $m g k g-1$ & $m g k g-1$ & $m g k g-1$ & $m g k g-1$ & $\%$ & Ratio \\
\hline MANR & $0.14 \pm 0.02$ & $2.8 \pm 0.0$ & $1.00 \pm 0.01$ & $4.75 \pm 0.22$ & $66 \pm 2.5$ & $36 \pm 2.6$ \\
RCW & $0.20 \pm 0.05$ & $2.2 \pm 0.75$ & $0.21 \pm 0.03$ & $0.61 \pm 0.10$ & $85 \pm 0.5$ & $74 \pm 20$ \\
BSG & $0.12 \pm 0.02$ & $5.8 \pm 0.20$ & $1.08 \pm 0.03$ & $0.39 \pm 0.02$ & $96 \pm 0.0$ & $18 \pm 0.9$
\end{tabular}

2 SOIL MEASUREMENTS

\begin{tabular}{|c|c|c|c|c|c|c|c|}
\hline & Analyte & $\mathbf{N H}_{3-4}$ & $\mathrm{NO}_{3-4}$ & Total N & TOC:N & $\mathrm{C}_{10}-\mathrm{C}_{50}$ & Reduction \\
\hline Treatment & units & $m g \mathrm{~kg}-1$ & $m g k g-1$ & $m g k g-1$ & ratio & $m g k g-1$ & $\%$, rank \\
\hline \multirow{3}{*}{ FERT } & June & $61 \pm 29$ & $78 \pm 8$ & $196 \pm 50$ & $44: 02.5$ & $7500 \pm 100$ & \multirow{3}{*}{$62 \pm 4 b$} \\
\hline & & & & & & & \\
\hline & Nov. & $10 \pm 0$ & $0.5 \pm 0$ & $243 \pm 12$ & $01: 02.5$ & $2833 \pm 252$ & \\
\hline \multirow{3}{*}{ MANR-F } & June & $76 \pm 13$ & $60 \pm 5$ & $420 \pm 60$ & $18: 02.5$ & $6500 \pm 173$ & \multirow{3}{*}{$77 \pm 3 \mathrm{a}$} \\
\hline & & & & & & & \\
\hline & Nov. & $10 \pm 0$ & $1.3 \pm 0.8$ & $363 \pm 12$ & $45: 02.5$ & $1500 \pm 200$ & \\
\hline \multirow{3}{*}{ RCW-F } & June & $66 \pm 16$ & $68 \pm 13$ & $330 \pm 12$ & $10: 02.5$ & $6767 \pm 58$ & \multirow{3}{*}{$60 \pm 6 b$} \\
\hline & & & & & & & \\
\hline & Nov. & $10 \pm 0$ & $0.5 \pm 0$ & $283 \pm 22$ & $00: 02.5$ & $2700 \pm 400$ & \\
\hline \multirow{3}{*}{ BSG-F } & June & $10 \pm 0$ & $40 \pm 16$ & $990 \pm 87$ & $52: 02.5$ & $7133 \pm 58$ & \multirow{3}{*}{$38 \pm 11 \mathrm{c}$} \\
\hline & & & & & & & \\
\hline & Nov. & $80 \pm 35$ & $4 \pm 3.5$ & $733 \pm 55$ & $33: 02.5$ & $2700 \pm 400$ & \\
\hline
\end{tabular}

